\title{
LARYNGOTRACHEITIS: REPRODUCIBILITY OF THE DISEASE AND COMPARISON OF DIAGNOSTIC METHODS
}

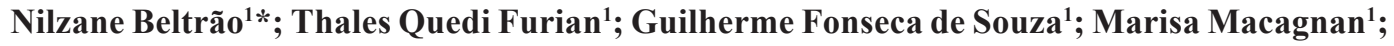 \\ Luiz César Bello Fallavena ${ }^{2}$; Claudio Wageck Canal ${ }^{1}$ \\ ${ }^{1}$ Centro de Diagnóstico e Pesquisa em Patologia Aviária, Faculdade de Veterinária, Universidade Federal do Rio Grande do Sul, \\ Porto Alegre, RS, Brasil. ${ }^{2}$ Universidade Luterana do Brasil, Canoas, RS, Brasil.
}

This paper corresponds to an "extended abstract" selected for oral presentation in the $22^{\text {nd }}$ Brazilian Congress of Microbiology, held in Florianópolis, SC, Brazil, in November 17-20, 2003

\begin{abstract}
Infectious laryngotracheitis virus (ILTV) cause mild to severe respiratory disease in chickens, the purpose of our study being to use Brazilian isolate of ILTV to reproduce ILTV disease in chickens by experimental infection and to compare three diagnostic methods (nested polymerase chain reaction (PCR), virus isolation, histopathology) for detection of ILTV. Forty-eight chickens intratracheally inoculated with ILTV and a further 48 with PBS, showing mild respiratory signs 48 hours post infection (PI) but no signs of infection after day 10 PI. Every 2 days PI, six birds were arbitrarily selected from the control and infected groups, sacrificed and the trachea collected. Both the nested PCR and virus isolation detected the virus from day 2 until day 12 PI. However, at day 12 PI, PCR detected ILTV DNA in $100 \%$ of the samples while the virus isolation method detected ILTV in only $33 \%$ of the samples. Tracheal histopathology showed intranuclear inclusion bodies on days 8 and 10 PI. The results indicate that the field-isolate of ILTV studied by us is of low pathogenicity and that our nested PCR protocol was able to detect positive samples over a longer infection period than many ILTV diagnostic test already described.
\end{abstract}

Key words: infectious laryngotracheitis virus, avian pathology, diagnosis.

\section{INTRODUCTION}

Infectious laryngotracheitis virus (ILTV) is a member of the Herpesviridae family that cause severe or mild respiratory disease in chickens. Various techniques have been described for the detection of ILTV, including the polymerase chain reaction (PCR) $(1,2)$, virus isolation $(3,4)$ and histopathology $(4)$. The distribution of ILTV is worldwide (4). The virus was detected in Brazil in 1974 but since then there have been no outbreaks in Brazil. We have previously described the isolation of some fieldvirus strains (5), the purpose of the present study being to reproduce the disease with one of the Brazilian ILTV isolates through the experimental infection of chickens and to compare three diagnostic methods (nested PCR, virus isolation and histopathology) for their ability to detect ILTV.

\section{MATERIALS AND METHODS}

\section{Viruses}

The ILTV positive control was the vaccine strain from Laryngovac of Solvay Animal Health (Charles City, Illinois, USA). The field-isolate used was obtained from layer-hens with respiratory illness collected in the southeast region of Brazil in 2002 (5). The virus was grown and titrated in 9 day-old embryonated eggs.

\section{Experimental infection}

Ninety-six broilers from a commercial lineage were reared in an isolation facility. At 6 weeks of age they were divided into two groups of 48 birds (infected and control group). On day zero the chickens were intratracheally inoculated with $0.2 \mathrm{~mL}$ the ILTV field-strain containing $0.2 \times 10^{4} \mathrm{EID}_{50}$ (median embryo

*Corresponding author. Mailing address: Centro de Diagnóstico e Pesquisa em Patologia Aviária, Faculdade de Veterinária, Universidade Federal do Rio Grande do Sul. Av. Bento Gonçalves, 8824, Agronômia. 91540-000. Porto Alegre, RS, Brasil. E-mail: nilzaneb@terra.com.br 
infective dose), the control group being inoculated with the same volume of PBS. On days 2, 4, 6, 8, 10 and 12 post infection (PI), six birds were arbitrarily selected from each group, sacrificed and their tracheas collected separately and tested.

\section{Virus isolation}

Each trachea was ground in a mortar and pistil and suspended in PBS which was then centrifuged to remove cell debris. For each trachea, $0.2 \mathrm{~mL}$ of the supernatant was inoculated into the chorioallantoic membrane (CAM) of a 9-day-old embryonated egg which was then incubated for 7 days and the $\mathrm{EID}_{50}$ estimated from the number of opaque plaques on the CAM.

\section{Histopathology}

The CAMs and the tracheas were fixed in $10 \%$ formalin. The fixed samples were processed through graded alcohol, embedded in paraffin, sectioned, and stained with haematoxylin and eosin.

\section{PCR}

The DNA was extracted by the phenol-chloroform method (1). Two sets of nested primers were selected from the published sequence data for the ILTV thymidine kinase (TK) gene (1), the internal primers ILTV/PCR 5' and ILTV/PCR 3' (p1 and p2) were as previously described (1) while the external primers (p3 and p4) were selected to increase sensitivity. The first PCR reaction with primers $\mathrm{p} 3$ and $\mathrm{p} 4$ was performed for 30 cycles, followed by another 30 cycles with the $\mathrm{p} 1$ and $\mathrm{p} 2$ primers. PCR products were analyzed by electrophoresis in a $1.2 \%$ agarose gel stained with ethidium bromide.

\section{RESULTS AND DISCUSSION}

Experimentally infected chickens showed mild respiratory signs 48 hours PI, including depression and dyspnea, no respiratory signs being observed after day 10 PI. Two birds died between days 8 and 10 PI displaying hemorrhagic tracheal exudates. The results indicate that the ILTV field-isolate is a sample of low pathogenicity. Virus isolation detected ILTV from day 2 to day $12 \mathrm{PI}$, all tracheas positive by the virus infection assay also producing the expected $647 \mathrm{bp}$ PCR amplification product and thus being positive by the nested PCR test (Fig. 1). On day 12 PI, the PCR was positive in $100 \%$ of the samples but the virus infection test was positive only in $33.33 \%$ the samples, syncytia and inclusion bodies being histopathologically detected in the tracheal sections from day 6 and 8 PI. Comparison of the results of the three diagnostic tests performed on poultry infected with ILTV suggested that PCR was the more sensitive. Some authors have described experimental studies which indicate that ILTV is not detected, or is inconsistently detected, 6 days PI by different diagnostic tests $(2,3,4)$. Our results indicate that the nested PCR protocol was able to detect positive samples over a wider infection period than many ILTV diagnostic test already described.

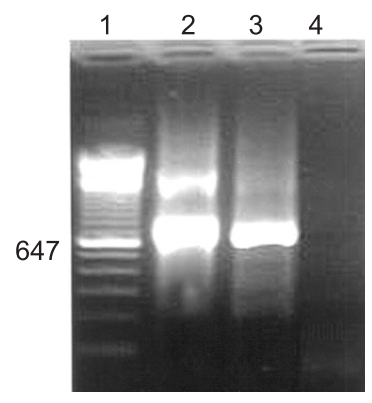

Figure 1. PCR products on a $1.2 \%$ agarose gel stained with ethidium bromide. Lane 1: 100 bp molecular weight marker; Lane 2: Vaccine strain; Lane 3: Tracheal swab from an inoculated bird; Lane 4: Tracheal swab from a non-inoculated bird.

\section{RESUMO}

\section{Laringotraqueíte: reprodutibilidade da doença e comparação de métodos de diagnóstico}

O vírus da laringotraqueíte (VLT) causa de leve a severa doença respiratório em galinhas, o propósito do nosso estudo foi usar um isolado brasileiro de VLT para reproduzir a doença em frangos através da infecção experimental e comparar três métodos de diagnóstico (nested PCR, isolamento viral e histopatologia) para detectar o VLT. Quarenta e oito frangos inoculados intratraquealmente com VLT e outros 48 com PBS, apresentaram sinais respiratórios leves 48 horas após a infecção (PI), mas nenhum sinal após o dia 10 PI. A cada dois dias, seis aves foram selecionados arbitrariamente do controle e do grupo infectado, sacrificados e as traquéias coletadas. Ambos nested PCR e isolamento viral detectaram o vírus do dia 2 até o dia 12 PI. No entanto, no dia 12 PI, a PCR detectou o DNA viral em $100 \%$ das amostras enquanto o isolamento viral detectou em somente $33 \%$ das amostras. Histopatologia da traquéia revelou corpúsculos de inclusão intranuclear nos dias 8 e 10 PI. Os resultados indicam que o VLT isolado de campo estudado é de baixa patogenicidade e que o protocolo de Nested PCR foi capaz de detectar amostras positivas por um período mais longo da infecção do que muitos testes de diagnósticos descritos.

Palavras-chave: vírus da laringotraqueíte infecciosa, patologia aviaria, diagnóstico.

\section{REFERENCES}

1. Abbas, F.; Andreasen, R.J.; Jackwood, M.W. Development of Polymerase chain reaction and a nonradioactive DNA probe for infectious laryngotracheitis virus. Avian Dis., 40:56-62, 1996.

2. Abbas, F.; Andreasen, R.J. Comparison of diagnostic tests for infectious laryngotracheitis. Avian Dis., 40:290-295, 1996.

3. Alexander, H.S.; Nagy, E. Polymerase chain reaction to detect infectious laryngotracheitis virus in conjunctival swabs from experimentally infected chickens. Avian Dis., 41:646-693, 1997.

4. Bagust, T.J.; Guy, J.S. Laryngotracheitis. In: Calnek, B.W.; Barnes, H.J.; Beard, C.W.; McDougald, L.R.; Saif, Y.M. (eds). Diseases of Poultry, 10th ed., (Ames, Iowa State University Press), 1997, p. 527-539.

5. Beltrão, N.; Leao, J.A.; Rocha, S.L.S.; Furian, T.Q.; Junior, B.A. Detection of infectious laryngotracheitis virus from poultry by a nested-PCR. Virus Rev. Res., 7:113, 2002. 